\title{
The Amount and Source of Millionaires' Wealth (Moderately) Predict Their Happiness
}

\section{Citation}

Donnelly, Grant E., Tianyi Zheng, Emily Haisley, and Michael I. Norton. 2018. “The Amount and Source of Millionaires' Wealth (Moderately) Predict Their Happiness." Personality and Social Psychology Bulletin 44 (5) (January 11): 684-699. doi:10.1177/0146167217744766.

\section{Published Version}

10.1177/0146167217744766

\section{Permanent link}

http://nrs.harvard.edu/urn-3:HUL.InstRepos:37221623

\section{Terms of Use}

This article was downloaded from Harvard University's DASH repository, and is made available under the terms and conditions applicable to Open Access Policy Articles, as set forth at http:// nrs.harvard.edu/urn-3:HUL.InstRepos:dash.current.terms-of-use\#OAP

\section{Share Your Story}

The Harvard community has made this article openly available.

Please share how this access benefits you. Submit a story.

\section{Accessibility}




\title{
Running Head: THE HAPPINESS OF MILLIONAIRES
}

The Amount and Source of Millionaires’ Wealth (Moderately) Predicts Their Happiness

\author{
Grant E. Donnelly
}

Harvard Business School

\author{
Tianyi Zheng \\ University of Mannheim
}

\author{
Emily Haisley \\ BlackRock
}

Michael I. Norton

Harvard Business School

Word count $=8,709$ 


\begin{abstract}
Two samples of more than four thousand millionaires reveal two primary findings. First, only at high levels of wealth - in excess of \$8 million (Study 1) and \$10 million (Study 2) - are wealthier millionaires happier than millionaires with lower levels of wealth, though these differences are modest in magnitude. Second, controlling for total wealth, millionaires who have earned their wealth are moderately happier than those who inherited it. Taken together, these results suggest that, among millionaires, wealth may be likely to pay off in greater happiness only at very high levels of wealth, and when that wealth was earned rather than inherited.
\end{abstract}

Keywords: happiness, income, money, wealth, well-being 
The Amount and Source of Millionaires' Wealth (Moderately) Predicts Their Happiness Many people aspire to great wealth, and becoming a millionaire is a commonly used reference for financial success (Kasser \& Ryan, 1993); moreover, people tend to think that more money is related to more happiness (Aknin, Norton, \& Dunn, 2009; Myers, 2000a). But does great wealth bring great happiness? If so, how much wealth is required? And, does the manner in which that wealth is accrued - whether you earned it yourself, or inherited it - predict the amount of happiness experienced? We use two large and unique samples of millionaires to shed novel light on these fundamental questions about the relationship between money and happiness.

A large body of cross-sectional survey research demonstrates that overall life satisfaction continues to rise with income, though typically with diminishing marginal return (e.g., Aknin et al., 2009; Kahneman \& Deaton, 2010; Myers, 2000b; Stevenson \& Wolfers, 2008). However, the vast majority of the data informing our understanding of this relationship is derived from samples that have relied heavily on average earners (e.g., Cummings, 2000) and the poor (Biswas-Diener \& Diener, 2006). For instance, Cummings (2000) meta-analytically reviewed effect sizes from 31 studies that investigated the relation between subjective wellbeing and income. Only one of these samples included individuals who made more than $\$ 150,000$ annually. Additionally, many studies investigating the influence of wealth on happiness have utilized large panel data sets (e.g., Diener, Ng, Harter, \& Arora, 2010; Kahneman \& Deaton, 2010; Ng \& Diener, 2014). These datasets, while large, are also typically representative of the sample populations and only identify a small number of "wealthy” participants as making over $\$ 150,000$ a year. Further, many convenience samples (e.g., Aknin et al., 2009; Diener \& 
Diener, 2009; Diener, Tay, \& Oishi, 2013; Johnson \& Krueger, 2006) are also missing data from wealthy individuals - likely because they are less likely to respond to requests to complete surveys (see Page, Bartels, \& Seawright, 2013).

Compounding this issue, comparisons of well-being at the individual level have relied primarily on personal or household annual income (e.g., Blanchflower \& Oswald, 2004; Di Tella, Haisken-De New, \& MacCulloch, 2010; Diener \& Diener, 2009; Kahneman \& Deaton, 2010), which typically has a more restricted range than people’s net worth - which can be accumulated over time and includes all assets in addition to income (Headey \& Wooden, 2004). A number of large panel data sets include a small proportion of participants who report a relatively high annual household income (datasets and proportion of sample with annual household income exceeding the top value listed in parentheses: the United States General Social Survey [12.6\% over \$110,000], the German Socio-Economic Panel [.67\% over \$120,000], the National Longitudinal Survey [.84\% over \$150,000], the United States National Survey of Midlife Development [6.07\% over \$150,000], and the Taiwan Social Change Survey [7.68\% over \$150,000]). These top income levels are much lower than the wealth levels in our samples, and these surveys do not break down these high income respondents into even smaller buckets of very high income respondents, such that there are not sufficient numbers of high net worth individuals to compare to our samples. In sum, previous analyses of the relationship between money and happiness have typically been subject to a restricted range problem at the higher end in particular.

One approach towards understanding the relationship between wealth and wellbeing among the wealthy has been to evaluate lottery winners. However, research on 
lottery wins has also failed to evaluate large samples of wealthy individuals, typically focusing on individuals who won small sums, with just a handful of "big winners." For instance Brickman, Coates and Janoff-Bulman (1978) compared 22 lottery winners (with average winnings of $\sim \$ 480,000$ ) to non-winners from the same geographical areas. Lottery winners were not found to be any happier than control participants, but did report taking less pleasure in ordinary activities (e.g., socializing with friends, watching television). When Gardner and Oswald (2007) compared 137 lottery winners (average winnings $\sim \$ 200,000$ ) to both non-winners and individuals who won smaller sums, the larger winners experienced greater mental stress that year, and a small improvement in psychological wellbeing after two years. Taken together these studies suggest that medium-sized windfalls may have a small impact toward improving wellbeing.

Insight into the happiness of millionaires is limited to a single, sample from the 1983 Forbes list of wealthiest Americans (Diener, Horwitz, \& Emmons, 1985). In this study, 49 wealthy individuals (each with a net worth over \$125M) were compared to average earners from the same geographical areas. The very rich were, on average, somewhat happier than the average earners and reported moderately more satisfaction with life. The authors concluded that wealthier people are found to be happier than relatively poorer people, but the effects are small. However, this relative lack of data raises the question: does even more money bring even more happiness?

In addition to the relationship between happiness and the sheer amount of wealth, we also investigate whether the source of that wealth predicts the happiness associated with it. Certainly, the manner in which people spend their money has been shown to influence happiness, with spending on experiences (Gilovich \& Kumar, 2015; Van Boven 
\& Gilovich, 2003) and spending on others and giving to charity (Dunn, Aknin, \& Norton, 2008; 2014) typically associated with greater happiness than spending on material goods for the self. In addition, research has explored how the source of money affects subsequent spending of that money: framing money as a windfall versus an anticipated gain (Arkes et al., 1994), describing tax refunds as rebates versus bonuses (Epley \& Gneezy, 2007), and making the source of a monetary gift as a relative versus an ill relative (Levav \& McGraw, 2009) have all been shown to influence future spending.

Building on this previous research, we explore whether the manner in which wealth is acquired - the source of wealth - is a predictor not of spending, but of happiness. Andrew Carnegie opined that a parent leaving their child "enormous wealth generally deadens the talents and energies of the child, leading to a less useful and less worthy life than they otherwise would” (Carnegie, 1962). Indeed, receiving a large inheritance significantly decreases people's labor force participation, offering some supporting evidence for this "Carnegie Conjecture" that inherited wealth leads to a decreased desire to work (Elinder, Erixson, \& Ohlsson, 2012; Holtz-Eakin, Joulfaian, \& Rosen, 1992). We explore whether Carnegie's words also apply to the well-being that people derive from their wealth - as a function of whether they earned or inherited it.

\section{Overview of the Studies}

We utilize data from two large samples of high-net-worth respondents. In Study 1, all respondents $(N=2,129,70.4 \%$ male, median age $=45-54$ years, sampled in 17 countries) reported a net worth of at least \$1.5 million (median = \$3-\$7.9 million; Figure 1) and high incomes (median annual income $=\$ 100,000$ - \$149,999; Figure 2). 
Respondents completed an item assessing their life satisfaction on a 7-point scale (Figure 3). In Study 2, all respondents $\left(N=2,026,73.2 \%\right.$ male, $M_{\text {age }}=54.5, S D=12.8$, sampled in 17 countries) reported a net worth of at least $\$ 1$ million (median $=\$ 2-\$ 4.9$ million; Figure 4) and high incomes (median annual income = \$100,000- \$149,999; Figure 5). Respondents completed an item assessing their level of happiness with their lives in general on a 10-point scale (Figure 6). In both samples, net worth and income were converted to US dollars, and respondents indicated the sources of their wealth, allowing us to calculate the percentage of earned wealth sources (e.g., from savings through earnings) and the percentage of unearned wealth sources (e.g., from an inheritance or marriage).

\section{Methods}

\section{Respondents and Design}

Ledbury Research conducted both surveys on behalf of a large financial institution in January 2012 and 2013 for commercial purposes; we use a subset of questions from the full survey instrument for our analyses. Per the stated guidance of the Harvard Business School Institutional Review Board for research using commercial data sets, we received approval for using data only after all respondent identifying information was removed.

\section{Study 1: Millionaires' Satisfaction with Life}

\section{Materials and Procedure}

Respondents were high-net-worth individuals $(N=2,129)$ sampled in 17 countries in which the financial institution operates: $24.1 \%$ in the United States, $24.4 \%$ in the 
United Kingdom, and 79.2\% in developed countries. Respondents were primarily male (70.4\%) and middle aged (median age group $=45-54$ years old). All respondents reported a net worth of at least $\$ 1.5$ million (median net worth $=\$ 3-\$ 7.9$ million), and high incomes (median annual income $=\$ 100,000-\$ 149,999$ ).

Respondents first rated their current net worth, defined as the total value of their savings, investments and assets minus any borrowing/mortgages (percentage endorsing each option in parentheses): (a) under $\$ 375,000$, (b) $\$ 375,000$ - $\$ 749,999$, (c) $\$ 750,000$ \$999,999, (d) \$1 million - \$1.49 million, (e) \$1.5 million - \$2.9 million (48.6\%), (f) \$3 million - \$7.9 million (28.2\%), (g) \$8 million - \$14.9 million (11.6\%), (h) 15 million + (11.6\%), (i) would rather not say. Respondents who indicated a net worth of under $\$ 1.5$ million or who responded (i) were screened out of the survey (a decision made by the survey organization prior to data collection).

Respondents then completed a series of questions included by the sponsoring organization. Finally, respondents rated their satisfaction with their life in general: "All things considered, I am satisfied with my life” on a 1 (Strongly Disagree) to 7 (Strongly Agree) scale. Such single-item measures assessing life satisfaction are commonly used in both panel data (e.g., Blanchflower \& Oswald, 2004; Lucas \& Donnellan, 2012) and convenience samples (e.g., Diener, Horwitz \& Emmons, 1985; Dunn et al., 2008) and have been found to be highly reliable (Abdel-Khalek, 2006).

Respondents reported their individual income on an annual basis, including any bonuses and/or investment income (percentage endorsing each option in parentheses): (a) no current income (1.2\%), (b) under \$50,000 (34.6\%), (c) \$50,000 - \$99,000 (10.4\%), (d) $\$ 100,000$ - \$149,999 (9.1\%), (e) \$150,000 - \$199,999 (6.2\%), (f) $\$ 200,000$ - \$249,999 
(5.0\%), (g) \$250,000 - \$499,999 (9.6\%), (h) \$500,000 - \$999,999 (17.1\%), (i) 1 million + (3.4\%), (j) prefer not to answer (3.4\%). The few respondents ( $n=25)$ who chose (a) were grouped with those who chose (b) in the "under \$50,000" category; those who endorsed (j) were excluded from all analyses of income $(n=72)$.

All respondents were then asked, "Which of the following have contributed the most to your overall wealth?” with the following response options (percentage endorsing each option in parentheses): (a) inheritance (24.8\%), (b) spouse/partner (12.5\%), (c) savings through earnings/ bonuses over time (49.1\%), (d) profits/assets from business(es) (38.1\%), (e) large bonus (28.9\%), (g) personal investments (51.7\%), (h) profit from property (36.8\%), (i) other (6.2\%). Respondents could report multiple sources of wealth. We summed the total number of sources for each respondent, and the number of instances listed that wealth was inherited or the result of a spouse/marriage for each respondent; we divided these instances by the total number of sources to create a "percent of unearned wealth sources" variable.

To categorize these sources of wealth, we asked a sample of 100 participants from Amazon’s Mechanical Turk ( $M_{\text {age }}=38.87, S D=12.46 ; 50.0 \%$ female, $85.0 \%$ Caucasian $)$ to rate all sources of wealth on the extent they considered each to be earned on a 7-point scale (ranging from 1, definitely not earned, to 7, definitely earned). Participants rated the inheritance and spouse/partner sources as unearned (as demonstrated by mean ratings significantly lower than the midpoint of the 7-point scale; all $p s<.05$ ), and all other sources as being earned (with mean ratings significantly higher than the scale midpoint; all $p s<.001)$.

\section{Results}


Net worth and personal income data were assessed in banded groups; we therefore created banded dummies for these variables in our analyses (see Table 1 for means, standard deviations and correlations among all study variables).

In Step 1 of a four-step hierarchical regression (Table 2), we included only net worth dummy variables as predictors of life satisfaction, using respondents who reported a net worth of $\$ 1.5-2.9 \mathrm{M}$ - the modal response - as the reference group (Field, 2009). In Step 2 we included demographic variables previously shown to predict life satisfaction (e.g., Kahneman \& Deaton, 2010; Di Tella \& MacCulloch, 2008; Vendrik, 2013): gender, age, a polynomial term for age, marital status, and being retired. In Step 3, we include respondents' country of residence variables, and coded dummy variables using United States as the reference group. In Step 4, we included the "percent of unearned wealth sources” measure of respondents' reports of the sources of their wealth.

Compared to respondents with a net worth of $\$ 1.5-2.9 \mathrm{M}$, respondents with a net worth of $\$ 3-7.9 \mathrm{M}$ were not more satisfied with life $(\beta=-.01 ; p=.62, d=.02)$; those with a net worth of $\$ 8-14.9 \mathrm{M}$ were significantly more satisfied $(\beta=.06, p=.004, d=.15)$, and those with a net worth of $\$ 15 \mathrm{M}+$ were marginally more satisfied $(\beta=.04, p=.09, d=$ .10). However, as Table 3 shows, these differences were small in absolute magnitude, with scores on a 7-point scale ranging from 5.79 to 5.97. These effects are consistent with, but relatively smaller than, effects observed for nationally representative samples at lower levels of wealth and income - where beta ranges from .06 to .40 (e.g., Blanchflower \& Oswald, 2004; Clark \& Oswald, 2002; Deaton, 2008; Diener, Sandvik, Seidlitz \& Diener, 1993; Di Tella \& MacCulloch, 2008; Di Tella, Haisken-De New \& MacCulloch, 2010; Di Tella, MacCulloch \& Oswald, 2003; Hagerty, 2000; Kahneman \& 
Deaton, 2010; Stevenson \& Wolfers, 2008; Vendrik, 2013) - perhaps demonstrating the marginal utility of wealth on well-being.

In addition, the percentage of wealth sources that was unearned was negatively related to life satisfaction $(ß=-.05, p=.02, d=.10)$, suggesting that earning rather than inheriting wealth is associated with greater happiness. However, as Table 4 shows, these differences were small in absolute magnitude, with scores on a 7-point scale ranging from 5.22 to 6.02. Life satisfaction was also predicted by gender (males were happier than females) and being married ( $p s<.01)$.

We next evaluated personal income as a predictor of happiness. We used the modal income group - respondents making $<\$ 50 \mathrm{~K}$ - as the reference group (Table 5), conducting the same 4-step regression as above but including banded income dummies in addition to banded wealth dummies. The pattern of results was unchanged for wealth when we included income. The only income group that differed from the $<\$ 50 \mathrm{~K}$ reference group were respondents with $\$ 1 \mathrm{M}+$ in income, though these respondents reported lower levels of satisfaction $(ß=-.05 ; p=.03, d=.18)$.

\section{Study 2: Millionaires’ Happiness}

To replicate our two primary findings from Study 1 - that very high levels of wealth are associated with significantly - though moderately - greater happiness, and that earned wealth is associated with greater happiness than inherited wealth, our second sample also included high net worth individuals recruited by Ledbury Research, using a similar survey with some small changes. First, well-being was assessed by general ratings of happiness: Respondents rated their current level of happiness with their lives in general, a measure used in previous research and correlates with measures of life 
satisfaction and demonstrates similar predictive ability (Di Tella \& MacCulloch, 2008; Di Tella, Haisken-De New \& MacCulloch, 2010; Howell \& Howell, 2008; Kahneman, Krueger, Schkade, Schwarz, \& Stone, 2004). Second, the survey organization included all participants with a net worth of over $\$ 1 \mathrm{M}$ (as opposed to $\$ 1.5 \mathrm{M}$ in Study 1), and assessed wealth in four slightly narrower banded groups. Third, household income was assessed rather than individual income; household income is a reliable predictor of wellbeing (Howell \& Howell, 2008). Finally, following previous research assessing the accuracy of people's predictions about the relationship between assets and happiness (Aknin et al., 2009; Cone \& Gilovich, 2010; Kahneman, Krueger, Schkade, Schwarz, \& Stone, 2006), we assess millionaires' beliefs about the impact of more wealth on their happiness.

\section{Materials and Procedure}

Respondents were high-net-worth individuals $(N=2,026)$ sampled in 17 countries in which the financial institution operates: $25.5 \%$ in the United States, $24.7 \%$ in the United Kingdom, and $67.7 \%$ in developed countries. Respondents were primarily male (73.2\%) and middle aged $\left(M_{\text {age }}=54.5, S D=12.8\right)$. All respondents reported a net worth of at least $\$ 1$ million (median net worth $=\$ 2-\$ 4.9$ million), and high incomes (median annual income $=\$ 100,000-\$ 149,999)$. Ledbury Research recruits high net worth individuals from a large global panel, making it unlikely that the same respondents completed both surveys; because data are deidentified, we cannot link the two data sets to crosscheck.

Respondents first rated their current net worth, defined as the total value of their savings, investments and assets minus any borrowing/mortgages (percentage endorsing 
each option in parentheses): (a) under $\$ 250,000$, (b) $\$ 250,000$ - $\$ 499,999$, (c) $\$ 500,000$ \$749,999, (d) \$750,000 - \$999,999, (e) \$1 million - \$1.9 million (49.0\%), (f) \$2 million \$4.9 million (32.4\%), (g) \$5 million - \$9.9 million (8.7\%), (h) \$10 million + (9.9\%), (i) would rather not say. Respondents who indicated a net worth of under $\$ 1$ million or who responded (i) were screened out of the survey (a decision made by the survey organization prior to data collection).

Respondents then completed a series of questions included by the sponsoring organization. Finally, respondents rated their general happiness: "How would you rate your current level of happiness with your life in general on a 1 to 10 scale, where 1 equals ‘Extremely Unhappy’ and 10 equals ‘Extremely Happy’?”

Respondents who did not answer " 10 ” to the happiness question were then asked, "What increase in your wealth do you think would move you one point higher on the scale?” and given six options: (a) no increase would change my happiness, (b) a 10\% increase in your current wealth, (c) a 50\% increase in your current wealth, (d) double your current wealth, (e) 5 times your current wealth, and (f) 10 times your current wealth. Only respondents who had not answered "no increase would change my happiness" to the 1-point increase question and had not reported a "9" or " 10 " to the happiness question, then answered "What increase in your wealth do you think would move you to a 10 on the scale (extremely happy)?” using the same six response options.

Respondents reported their household income on an annual basis, including any bonuses and/or investment income (percentage endorsing each option in parentheses): (a) no current income (0.2\%), (b) under \$50,000 (3.8\%), (c) \$50,000 - \$99,999 (21.6\%), (d) $\$ 100,000$ - \$149,999 (22.0\%), (e) \$150,000 - \$199,999 (11.9\%), (f) \$200,000 - \$249,999 
(8.7\%), (g) \$250,000 - \$499,999 (13.2\%), (h) \$500,000 - \$999,999 (5.1\%), (i) 1 million + (6.7\%), (j) prefer not to answer (6.8\%). The few respondents ( $n=4)$ who chose (a) were grouped with those who chose (b) in the "under $\$ 50,000$ " category; those who endorsed (j) were excluded from all analyses of income $(n=138)$.

All respondents were then asked, "Which of the following have contributed the most to your overall wealth?” with the following response options (percentage endorsing each option in parentheses): (a) inheritance (25.4\%), (b) spouse/partner (18.4\%), (c) savings through earnings/ bonuses over time (55.5\%), (d) profits/assets from business(es) (32.9\%), (e) profits/assets from business(es) (15.5\%), (f) large bonus (12.9\%), (g) personal investments (55.2\%), (h) profit from property (33.6\%), (i) other (1.1\%). Respondents could report multiple sources of wealth. We summed the total number of sources for each respondent, and the number of instances listed that wealth was inherited or the result of a spouse/marriage for each respondent; we divided these instances by the total number of sources to create a "percent of unearned wealth sources" variable.

\section{Results}

Net worth and household income data were assessed in banded groups, albeit in different bands than the previous sample; we again created banded dummies for these variables in our analyses (see Table 6 for means, standard deviations and correlations among all study variables). We used the same four-step hierarchical regression as Study 1 (Table 7), including the same variables as before in each step.

Compared to respondents with a net worth of $\$ 1-1.9 \mathrm{M}$, respondents with a net worth of either $\$ 2-4.9 \mathrm{M}$ or $\$ 5-9.9 \mathrm{M}$ were not happier ( $\beta s=.01$ and -.02 , $p s=.57$ and .40 , $d s=.02$ and .06); those with a net worth of $\$ 10 \mathrm{M}+$, however, were significantly happier 
$(ß=.06, p=.02, d=.16)$. However, as Table 8 shows, these differences were again small in absolute magnitude, with scores on a 10-point scale ranging from 7.72 to 8.03 . As in Sample 1, these effects were also consistent with, but relatively smaller than, effects observed in nationally representative samples at lower levels of wealth and income.

Also as in Sample 1, the percentage of wealth that was unearned was negatively related to happiness ( $\beta=-.05, p=.04, d=.09$ ). However, as Table 9 shows, these differences were again small in absolute magnitude, with scores on a 10-point scale ranging from 7.38 to 8.05 . Happiness was also significantly predicted by being married, and being retired $(p s<.007)$.

Predictions of the amount of wealth needed to increase happiness were similar across wealth levels. The most common response for a 1-point increase in happiness was “no increase” (36.8\%), followed by “100\% more” (22.3\%), and “50\% more” (18.4\%); this pattern did not differ by wealth, $\chi^{2}(15)=7.43, p=.95, d=.01$ (see Table 10). The percentage increase needed was larger for an increase in happiness to a "perfect 10," with “1,000\% more” the most frequent (26.8\%) followed by “500\% more” (24.5\%), and " $100 \%$ more" (23.2\%); this pattern again did not differ by wealth, $\chi^{2}(15)=16.62, p=$ $.34, d=.04$ (see Table 11). We note that "no increase would change my happiness" item is ambiguous, such that endorsing this item could either indicate that respondents were happy with the wealth they had (such that no change would affect their happiness), or that the level of wealth needed to change their happiness was unrealistically large (such that no increase exists that would affect their happiness). Despite this ambiguity, we note that for both questions, the majority of respondents reported a specific numerical change in wealth that they believed would change their happiness. 
We evaluated household income as a predictor of happiness, including all banded net worth and banded income variables in the same regression (Table 12), which did not change the pattern of results for net worth: again, only respondents worth \$10M+ were significantly happier than those worth $\$ 1-1.9 \mathrm{M}(\beta=.05, p=.04, d=.13)$. No income groups differed from the $<\$ 50 \mathrm{~K}$ reference group. Thus while both samples show converging evidence that high levels of wealth are associated with greater happiness, results for income are more mixed, with higher incomes in Study 1 negatively associated with life satisfaction but in Study 2 not associated with happiness. While we can only speculate, Study 1 assessed personal income and Study 2 household income, and these two metrics may relate to different aspects of well-being.

\section{Discussion}

Is greater wealth associated with greater well-being? Overall, using two large samples of millionaires with two measures of well-being (happiness in general and life satisfaction), we find consistent evidence that somewhat higher levels of wealth are not associated with higher well-being, but substantially higher levels (greater than \$8M in Sample 1, greater than $\$ 10 \mathrm{M}$ in Sample 2) are linked to modestly greater well-being.

Augmenting some models of the money-happiness link that suggest a "flattening out” of the curve once an income threshold has been reached - for example, $\$ 75,000$ (Kahneman \& Deaton, 2010) - our results suggest that the curve does not fully flatten out: great wealth does predict greater happiness. Research suggests that wealth can have mixed effects on happiness: while the wealthy are more likely to engage in some behaviors associated with increased well-being - such as volunteering at non-profit 
organizations (Dury et al., 2015; Tang et al., 2008), giving money to those in need (Smeets, Bauer, \& Gneezy, 2015), and donating their used items for reuse (Granzin \& Olsen, 1991) - they are less likely to engage in other behaviors linked to well-being such as behaving charitably toward others (Piff, Kraus, Cote, Cheng, \& Keltner, 2010). Our results suggest that despite these conflicting effects of wealth on the pursuit of happiness-inducing activities, sufficiently high wealth does indeed predict modestly greater happiness.

Why might greater wealth lead to greater happiness among millionaires? Diener, Horwitz and Emmon's (1985) study of millionaires shows that the wealthy believe that money increases their happiness when used to help others and the world, and that money provides increased freedom to choose leisure activities and friends. Indeed, wealth enables people to take greater control of their lives, by giving the wealthy greater autonomy over how they choose to spend their time (Gallo \& Matthews, 2003; Kraus, Piff, Mendoza-Denton, Rheinschmidt, \& Keltner, 2012), and such feelings have been associated with higher life satisfaction (Howell \& Howell, 2008). While a number of researchers have cited need theory to explain the diminishing marginal effect of wealth and well-being (e.g., Howell \& Howell, 2008), perhaps at the higher end, wealth increases millionaires’ sense of efficacy in carrying out goals (Lachman \& Weaver, 1998). In addition, it is possible that wealth helps millionaires' to achieve the fundamental human goal of high status (Anderson, Hildreth, \& Howland, 2015). While our datasets do not allow us to examine these potential mediating processes, we hope that future research explores these issues in more depth. 
In addition, both samples document a novel factor determining the wealthhappiness link: whether millionaires earned or inherited their wealth. While previous research has focused on the effect of spending money in different ways (Dunn et al., 2014; Gilovich \& Kumar, 2015), we focus instead on the effects on well-being of the manner in which money was acquired. Whereas previous research demonstrates that inheriting wealth can decrease desire for employment, we show that inheriting wealth has a psychological effect as well: the percentage of wealth that people earned serves as a positive predictor of general happiness. While we found the percentage of unearned wealth sources to negatively predict happiness, our data does not allow us to calculate the actual proportion of wealth that was earned or unearned. While a convenience sample evaluated receiving an inheritance and acquiring money through marriage as an unearned source of wealth, we cannot be certain that recipients of inheritances and wealth through marriage would evaluate these sources of wealth as being unearned. Future research should evaluate how perceptions of earning wealth impact well-being; one possibility is that the effort of earning leads people to value their wealth more, in the same way that effort leads people to more highly value social groups, consumer products, and even psychotherapy (Aronson \& Mills, 1959; Axsom \& Cooper, 1965; Norton, Mochon, \& Ariely, 2012). In sum, we show that, in addition to microeconomic factors that determine the relationship between money and happiness - such as economic inequality (Oishi, Kesebir, \& Diener, 2011) - a novel microeconomic factor shapes happiness: whether wealth was inherited or earned.

We note that, as in all cross-sectional data assessing the money-happiness link, our results are correlational: we can say neither that very high levels of wealth cause 
greater happiness, nor that earning wealth causes greater happiness than inheriting it. For example, causation may run in the opposite direction, with higher well-being leading to higher wealth (Lyubomirsky, King, \& Diener, 2005); indeed, happier people are more likely to obtain a college degree, to get promoted in their jobs, and to earn greater wealth (De Neve \& Oswald, 2012). We are also unable to assess whether inheritors and earners differ on other variables such as intelligence or conscientiousness, which may account for the differences in happiness we observe; for instance, our effects may vary as a function of the extent to which millionaires measure their self-worth on their financial success (Park, Ward, \& Naragon-Gainey, 2017). In addition, because the two samples assessed wealth using different banded groups, we are unable to identify a common "tipping point” in which happiness should be greatest, though the two samples do suggest that this tipping point occurs only at high levels of wealth compared to lower levels of wealth. And finally, while the sample sizes of our study are relatively large for this population millionaires - we cannot be certain that they are representative of millionaires in general (though of course, millionaires are by definition an unrepresentative group).

Still, taken together, these results suggest that millionaires’ belief that increased wealth is associated with increased happiness is more likely to be realized at high levels of wealth, and when they have earned it. 


\section{References}

Abdel-Khalek, A. M. (2006). Measuring happiness with a single-item scale. Social Behavior and Personality: An International Journal, 34(2), 139-150.

Aknin, L. B., Norton, M. I., \& Dunn, E. W. (2009). From wealth to well-being? Money matters, but less than people think. Journal of Positive Psychology, 4(6), 523-527.

Anderson, C., Hildreth, J. A. D., \& Howland, L. (2015). Is the desire for status a fundamental human motive? A review of the empirical literature. Psychological Bulletin, 141(3), 574-601.

Arkes, H. R., Joyner, C. A., Pezzo, M. V., Gradwohl-Nash, J., Siegel-Jacobs, K., \& Stone, E. (1994). The psychology of windfall gains. Organizational Behavior \& Human Decision Processes, 59, 331-347.

Biswas-Diener, R., \& Diener, E. (2006). The subjective well-being of the homeless, and lessons for happiness. Social Indicators Research, 76(2), 185-205.

Blanchflower, D. G., \& Oswald, A. J. (2004). Well-being over time in Britain and the USA. Journal of Public Economics, 88(7), 1359-1386.

Brickman, P., Coates, D., \& Janoff-Bulman, R. (1978). Lottery winners and accident victims: Is happiness relative? Journal of Personality and Social Psychology, 36(8), 917-927.

Carnegie, A. (1962). The advantages of poverty. In Edward C. Kirkland (Ed.), The gospel of wealth and other timely essays. Cambridge, MA: The Belknap Press of Harvard University Press: 50-77.

Cone, J., \& Gilovich, T. (2010). Understanding money’s limits: People’s beliefs about the income-happiness correlation. Journal of Positive Psychology, 5(4), 294-301. 
Cummings, R. A. (2000). Personal income and subjective well-being: A review. Journal of Happiness Studies, 1(2), 133-158.

De Neve, J., \& Oswald, A. J. (2012). Estimating the influence of life satisfaction and positive affect on later income using sibling fixed-effects. Proceedings of the National Academy of Sciences, 109(49), 19953-19958.

Diener, E., Diener, M. (2009). Cross-cultural correlates of life satisfaction and selfesteem. Journal of Personality and Social Psychology, 68, 653-663.

Diener, E., Horwitz, J., \& Emmons, R. A. (1985). Happiness of the very wealthy. Social Indicators Research, 16(3), 263-274.

Diener, E., Ng, W., Harter, J., \& Arora, R. (2010). Wealth and happiness across the world: Material prosperity predicts life evaluation, whereas psychosocial prosperity predicts positive feeling. Journal of Personality and Social Psychology, 99(1), 52-61.

Diener, E., Tay, L., \& Oishi, S. (2013). Rising income and the subjective well-being of nations. Journal of Personality and Social Psychology, 104(2), 267-305.

Di Tella, R., Haisken-De New, J., \& MacCulloch, R. (2010). Happiness adaptation to income and to status in an individual panel. Journal of Economic Behavior \& Organization, 76(3), 834-852.

Di Tella, R., \& MacCulloch, R. (2008). Gross national happiness as an answer to the Easterlin Paradox? Journal of Development Economics, 86(1), 22-42.

Dunn, E.W., Aknin, L.B., \& Norton, M.I. (2008). Spending money on others promotes happiness. Science, 319, 1687-1688.

Dunn, E.W., Aknin, L.B., \& Norton, M.I. (2014). Prosocial spending and happiness: 
Using money to benefit others pays off. Current Directions in Psychological Science, 23, 41-47.

Dury, S., De Donder, L., De Witte, N., Buffel, T., Jacquet, W., \& Verte, D. (2015). To volunteer or not: The influence of individual characteristics, resources, and social factors on the likelihood of volunteering by older adults. Nonprofit and Voluntary Sector Quarterly, 44(6), 1107-1128.

Elinder, M., Erixson, O., \& Ohlsson, H. (2012). The impact of inheritances on heirs' labor and capital income. The BE Journal of Economic Analysis \& Policy, 12(1), 1953-1982.

Epley, N., \& Gneezy, A. (2007). The framing of financial windfalls and implications for public policy. Journal of Socio-economics, 36, 36-47.

Field, A. (2009). Discovering statistics using SPSS. Sage Publications.

Gallo, L. C. \& Matthews, K. A. (2003). Understanding the association between socioeconomic status and physical health: Do negative emotions play a role? Psychological Bulletin, 129(1), 10-51.

Gardner, J. \& Oswald, A. J. (2007). Money and mental wellbeing: A longitudinal study of medium-sized lottery wins. Journal of Health Economics, 26(1), 49-60.

Gilovich, T., \& Kumar, A. (2015). We'll always have Paris: The Hedonic Payoff from Experiential and Material Investments. In M.P. Zanna and J.M. Olson (Eds.), Advances in experimental social psychology, Vol. 51, AESP, UK: Academic Press.

Granzin, K. L., \& Olsen, J. E. (1991). Characterizing participants in activities protecting 
the environment: A focus on donating, recycling and conservation behaviors. Journal of Public Policy \& Marketing, 1-27.

Headey, B., \& Wooden, M. (2004). The effects of wealth and income on subjective wellbeing and ill-being. The Economic Record, 80(1), S24-S33.

Holtz-Eakin, D., Joulfaian, D., \& Rosen, H. S. (1992). The Carnegie conjecture: Some empirical evidence. National Bureau of Economic Research (No. w4118).

Howell, R. T., \& Howell, C. J. (2008). The relation of economic status to subjective wellbeing in developing countries: A meta-analysis. Psychological Bulletin, 134(4), 536-560.

Johnson, W., \& Krueger, R. F. (2006). How money buys happiness: Genetic and environmental processes linking finances and life satisfaction. Journal of Personality and Social Psychology, 90(4), 680-691.

Kahneman, D., \& Deaton, A. (2010). High income improves evaluation of life but not emotional well-being. Proceedings of the National Academy of Sciences, 107(38), 16489-16493.

Kahneman, D., Krueger, A. B., Schkade, D. A., Schwarz, N., \& Stone, A. A. (2004). A survey method for characterizing daily life experience: The day reconstruction method. Science, 306(5702), 1776-1780.

Kahneman, D., Krueger, A. B., Schkade, D. A., Schwarz, N., \& Stone, A. A. (2006). Would you be happier if you were richer? A focusing illusion. Science, 312(5782), 1908-1910.

Kasser, T., \& Ryan, R. M. (1993). A dark side of the American dream: Correlates of financial success as a central life aspiration. Journal of Personality and Social 
Psychology, 65(2), 410-422.

Kraus, M., Piff, P. K., Mendoza-Denton, R., Rheinschmidt, M. L., \& Keltner, D. (2012). Social class, solipsism, and contextualism: How the rich are different from the poor. Psychological Review, 119(3), 546-72.

Lachman, M. E., \& Weaver, S. L. (1998). The sense of control as a moderator of social class differences in health and well-being. Journal of Personality and Social Psychology, 74(3), 763-73.

Levav, J., \& McGraw, A.P. (2009). Emotional accounting: How feelings about money influence consumer choice. Journal of Marketing Research, 46, 66-80.

Lyubomirsky, S., King, L. A., \& Diener, E. (2005). The benefits of frequent positive affect. Does happiness lead to success?. Psychological Bulletin, 131(1), 803-55.

Myers, D. G. (2000a). Wealth and well-being. In R. Stannard (Ed.), God for the $21^{\text {st }}$ Century, Randor, PA: Templeton Foundation.

Myers, D. G. (2000b). The funds, friends and faith of happy people. American Psychologist, 55(1), 56-67.

Ng, W., \& Diener, E. (2014). What matters to the rich and the poor? Subjective wellbeing, financial satisfaction, and postmaterialist needs across the world. Journal of Personality and Social Psychology, 107(2), 326-338.

Oishi, S., Kesebir, S., \& Diener, E. (2011). Income inequality and happiness. Psychological Science, 22, 1095-1100.

Page, B. I., Bartels, L. M., \& Seawright, J. (2013). Democracy and the policy preferences of wealthy Americans. Perspectives on Politics, 11(1), 51-73.

Park, L. E., Ward, D. E., \& Naragon-Gainey, K. (2017). It’s all about the money (for 
some): Consequences of financially self-worth. Personality and Social Psychology Bulletin, 43(5), 601-22.

Piff, P. K., Kraus, M. W., Cote, S., Cheng, B. H., \& Keltner, D. (2010). Having less, giving more: The influence of social class on prosocial behavior. Journal of Personality and Social Psychology, 99(5), 771-784.

Smeets, P., Bauer, R., \& Gneezy, U. (2015). The giving behavior of millionaires. Proceedings of the National Academy of Sciences, 34, 10641-10644.

Stevenson, B., \& Wolfers, J. (2008). Economic growth and subjective well-being: Reassessing the Easterlin paradox. National Bureau of Economic Research (No. w14282).

Tang, T. L. P., Sutarso, T., Davis, G. M. T. W., Dolinski, D., Ibrahim, A. H. S., \& Wagner, S. L. (2008). To help or not to help? The Good Samaritan Effect and the love of money on helping behavior. Journal of Business Ethics, 82(4), 865-887.

Van Boven, L., \& Gilovich, T. (2003). To do or to have: That is the question. Journal of Personality and Social Psychology, 85, 1193-1202.

Vendrik, M. C. (2013). Adaptation, anticipation and social interaction in happiness: An integrated error-correction approach. Journal of Public Economics, 105, 131-149. 
The Happiness of Millionaires 26

Figure 1. Net Worth $(N=2,129$; Study 1$)$

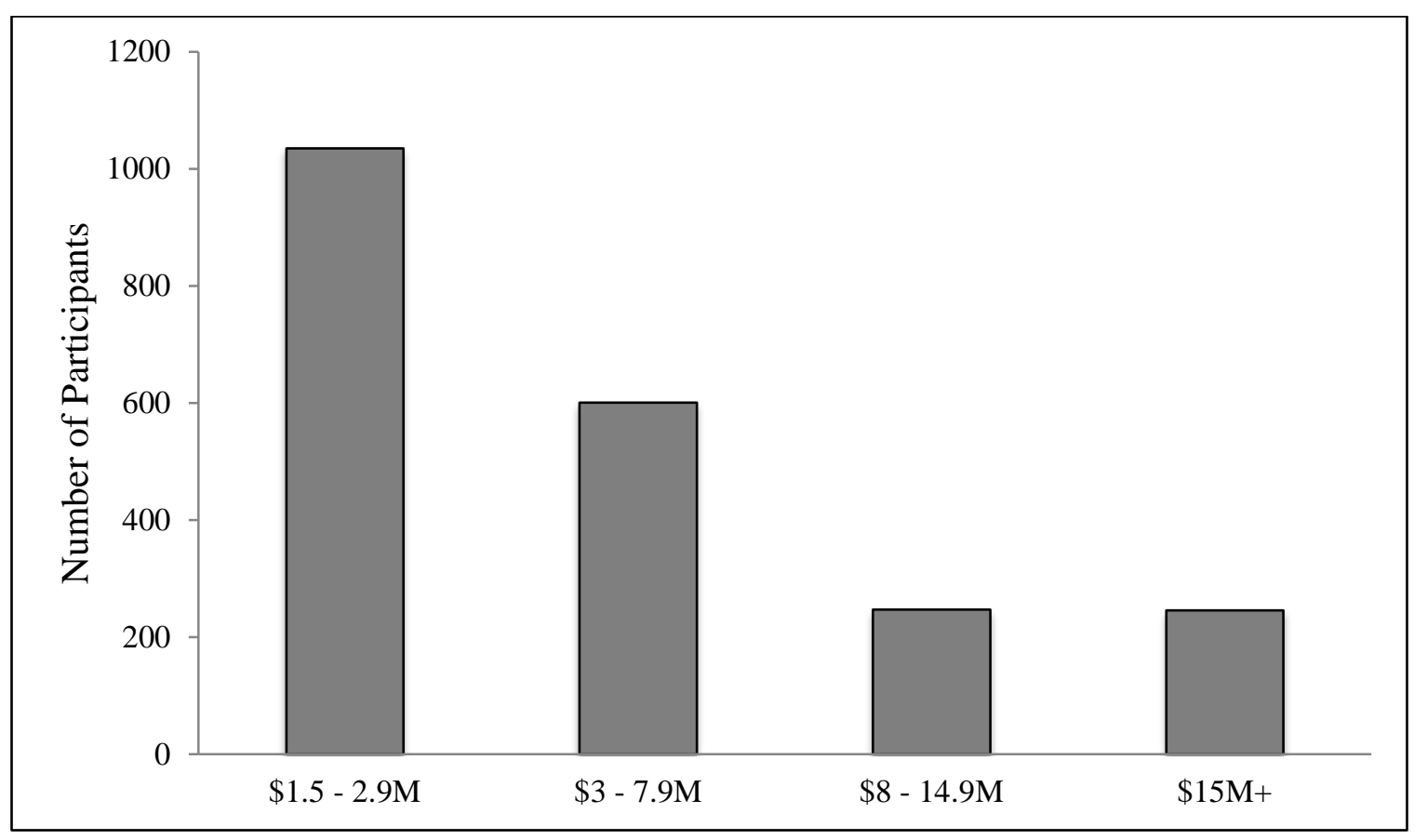


The Happiness of Millionaires 27

Figure 2. Individual Income ( $N=2,057$; Study 1$)$

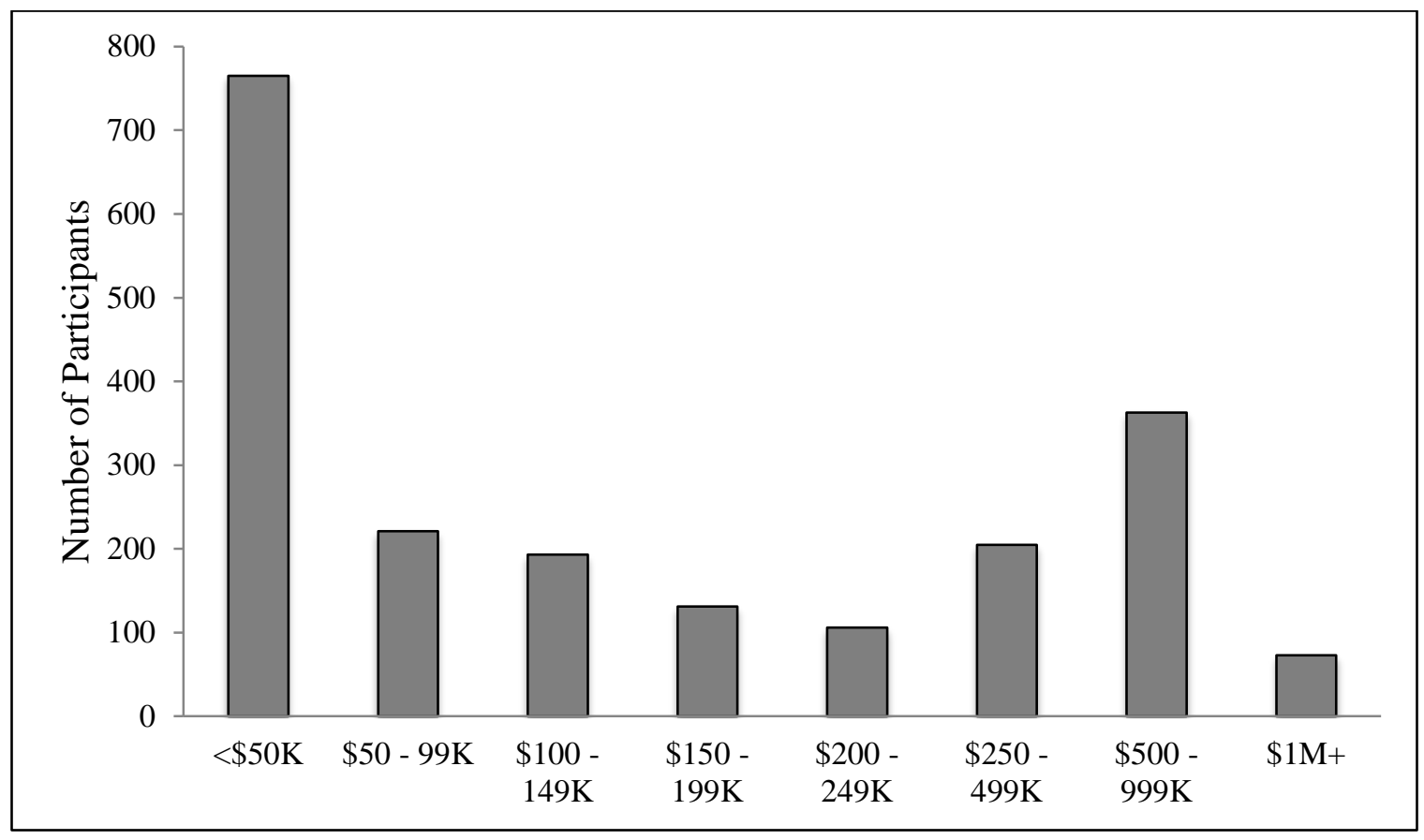


Figure 3. Satisfaction with Life ( $N=2,129$; Study 1$)$

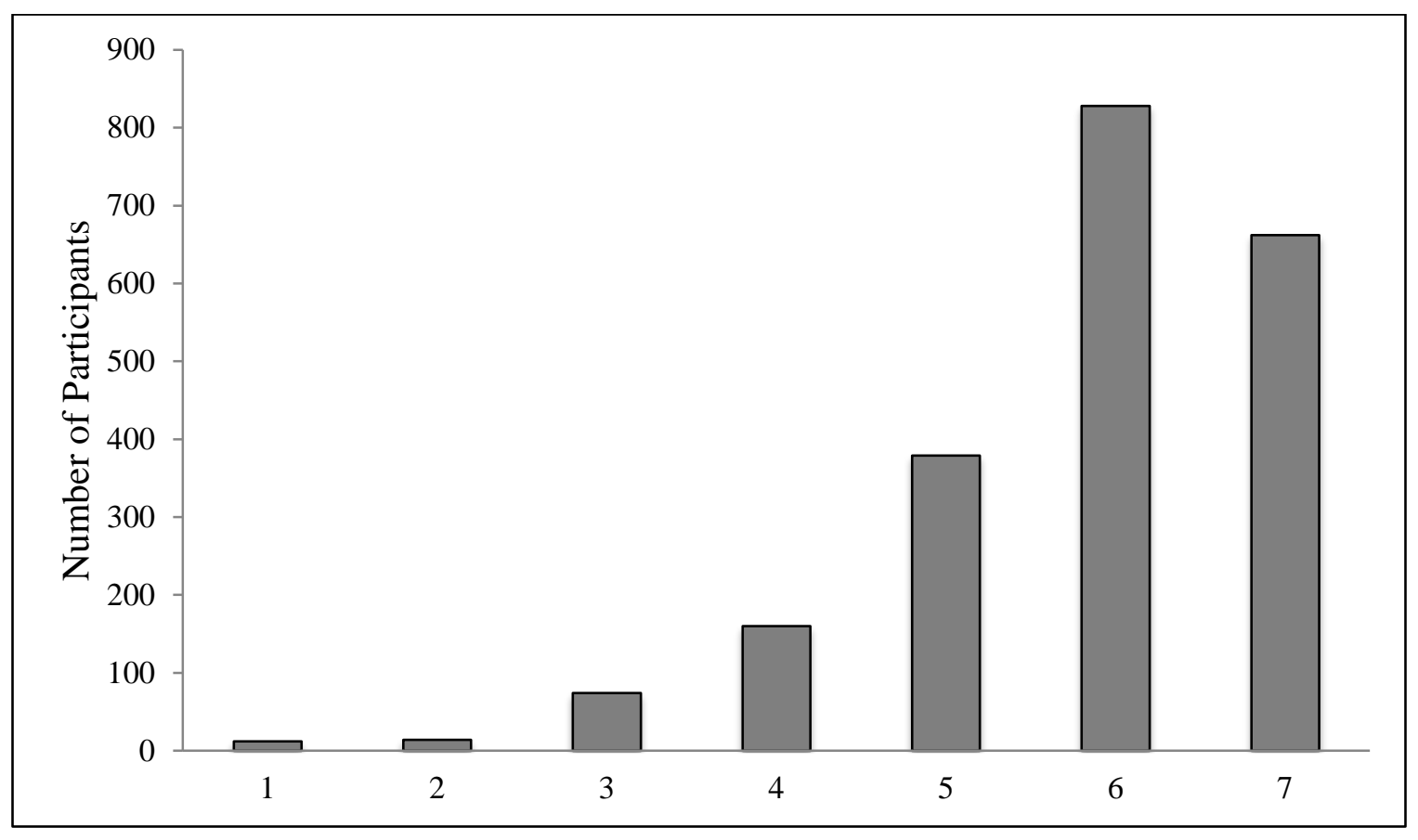

Note: Respondents were recorded on a 7-point scale (ranging from 1, strongly disagree to 7, strongly agree). 
The Happiness of Millionaires 29

Figure 4. Net worth $(N=2,026$; Study 2)

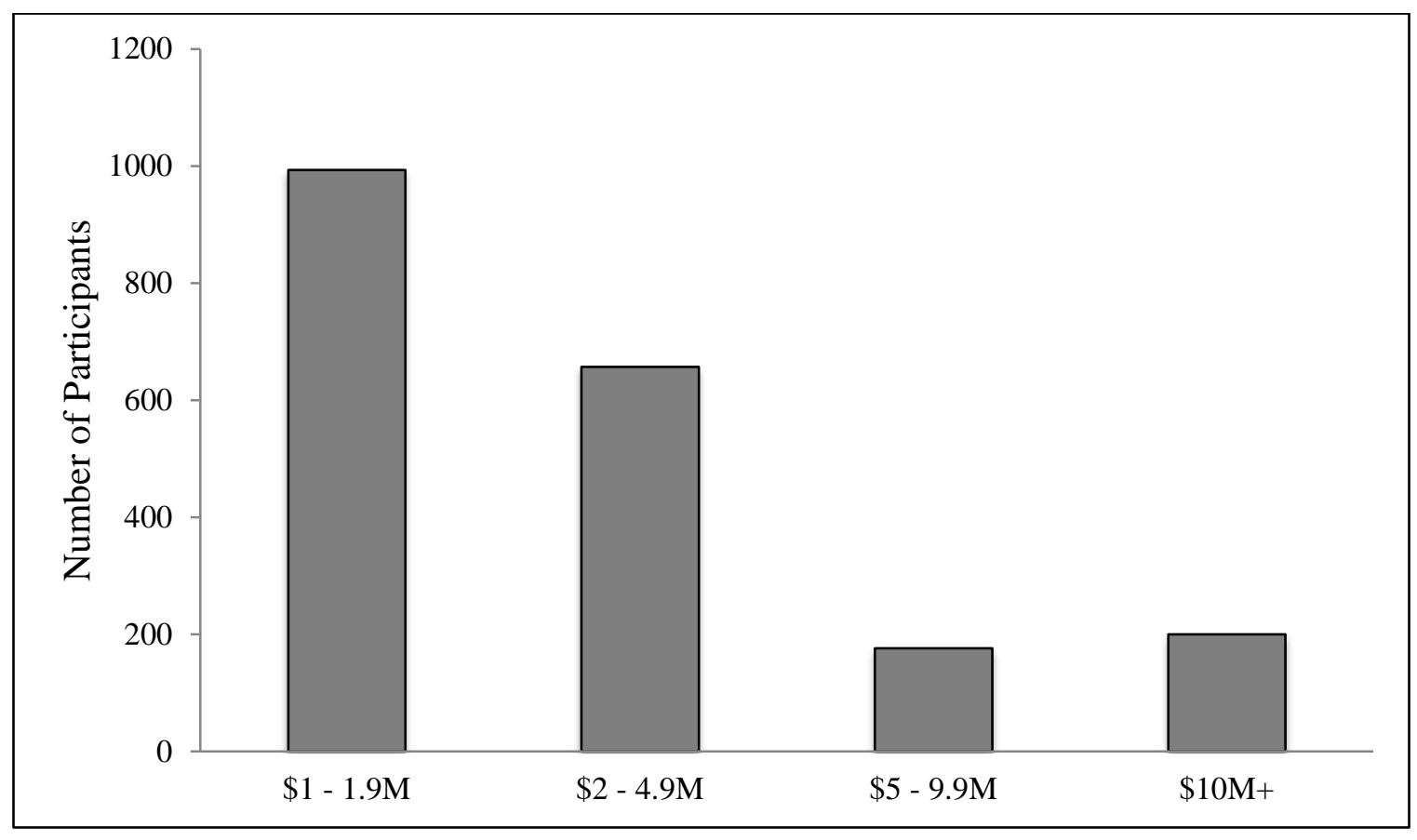


Figure 5. Household Income ( $N=1,888$; Study 2$)$

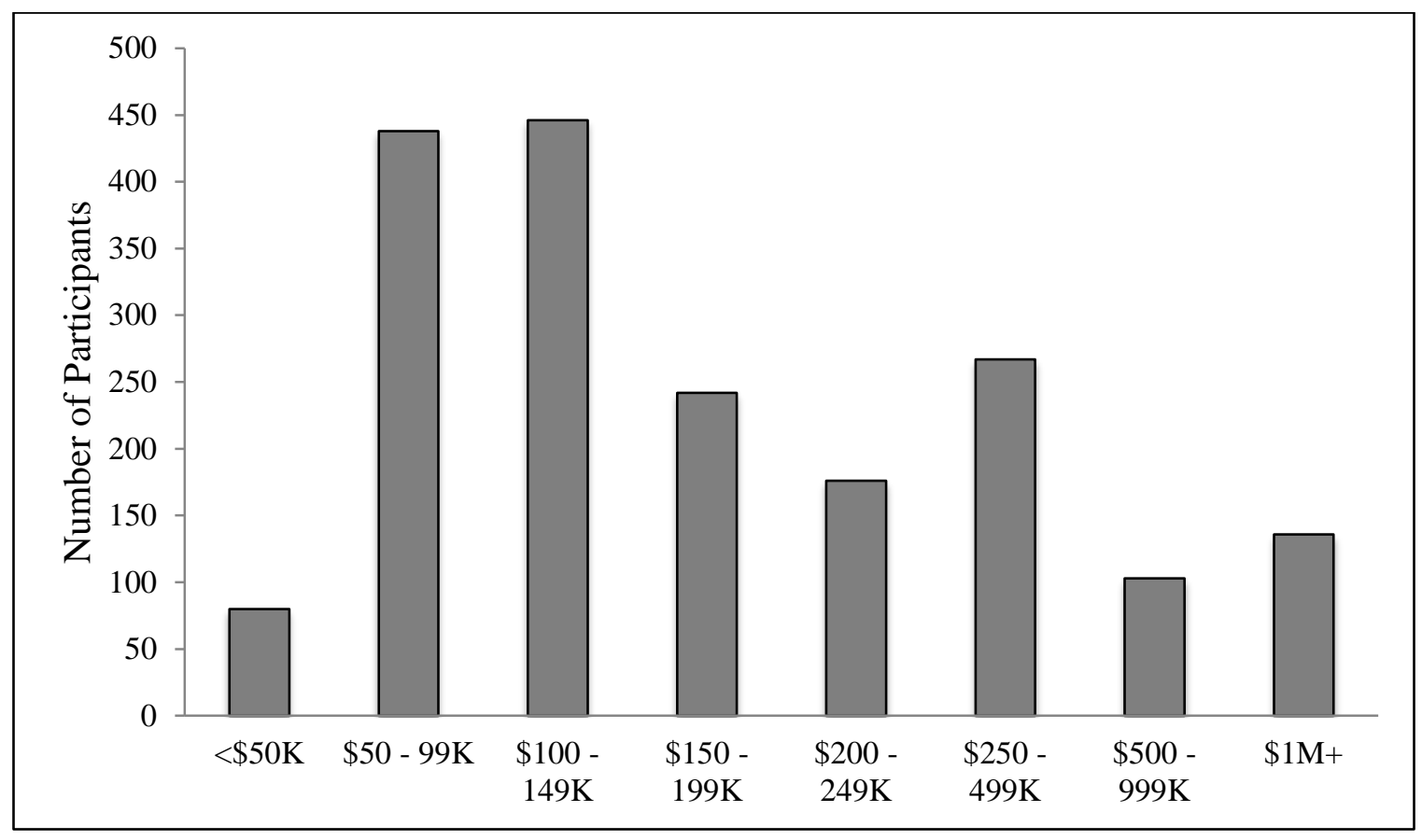


The Happiness of Millionaires 31

Figure 6. Happiness with Life $(N=2,017$; Study 2)

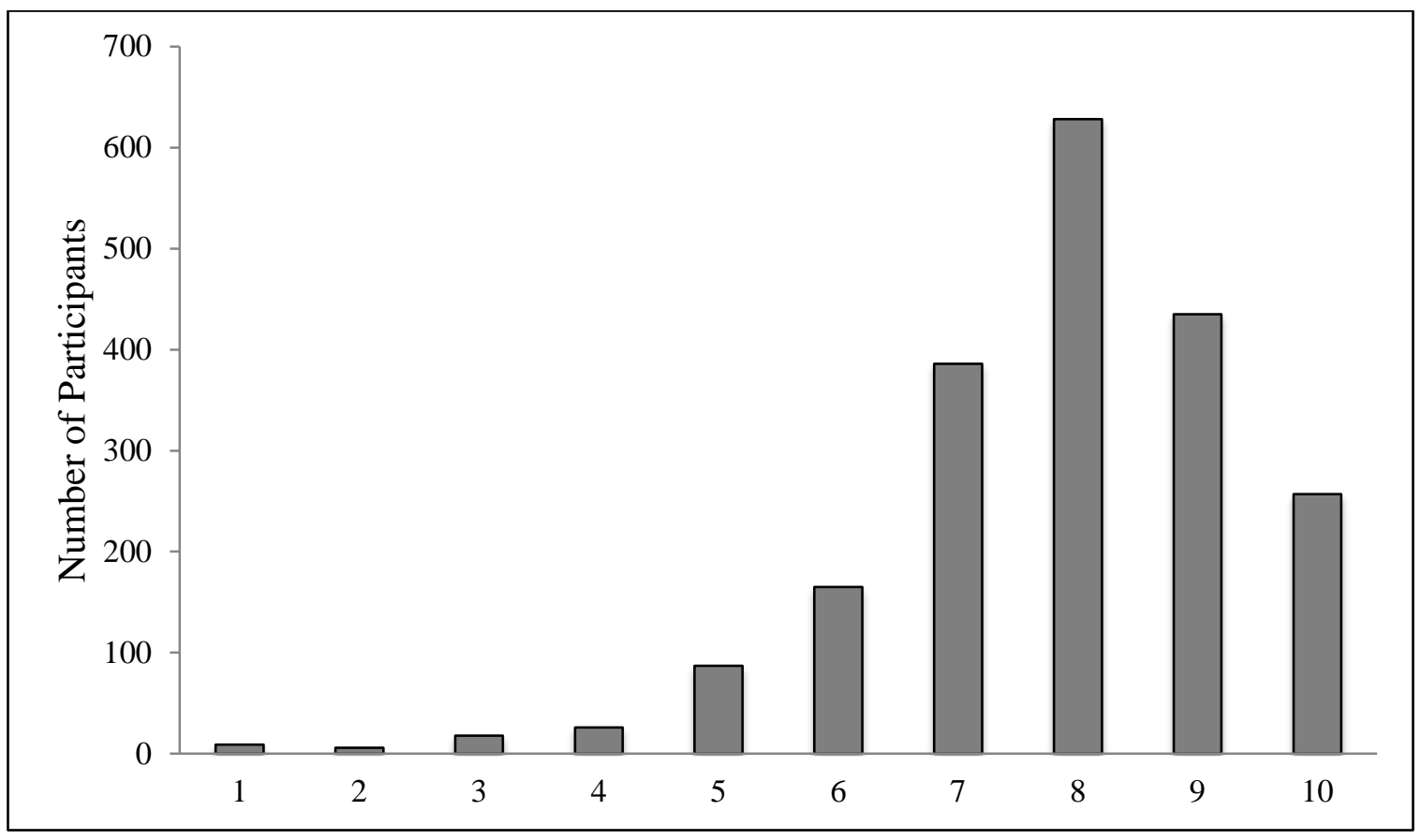


Table 1. Correlation Matrix (Study 1).

\begin{tabular}{|c|c|c|c|c|c|c|c|c|c|c|c|c|c|c|c|c|c|c|}
\hline & $M$ & $S D$ & 1 & 2 & 3 & 4 & 5 & 6 & 7 & 8 & 9 & 10 & 11 & 12 & 13 & 14 & 15 & 1 \\
\hline 1 & 5.82 & 1.15 & & & & & & & & & & & & & & & & \\
\hline 2 & 5.86 & 1.02 & .03 & & & & & & & & & & & & & & & \\
\hline 3 & 3.50 & 2.50 & $.08 * * *$ & $-.05^{*}$ & & & & & & & & & & & & & & \\
\hline 4 & .70 & .46 & -.02 & $.07 * * *$ & $-.12^{* * *}$ & & & & & & & & & & & & & \\
\hline 5 & 3.25 & 1.16 & $.20^{* * * *}$ & .03 & $.36 * * *$ & $.13^{* * * *}$ & & & & & & & & & & & & \\
\hline 6 & 11.89 & 7.31 & $.19^{* * *}$ & $.04^{+}$ & $.39 * * *$ & $.13^{* * *}$ & $.98^{* * *}$ & & & & & & & & & & & \\
\hline 7 & .79 & .40 & $.14^{* * *}$ & -.03 & $.06^{* *}$ & $.08^{* * *}$ & $.23^{* * *}$ & $.19^{* * *}$ & & & & & & & & & & \\
\hline 8 & .17 & .38 & $.14^{* * *}$ & .01 & $.62 * * *$ & $.04 *$ & $.46^{* * * *}$ & $.50^{* * *}$ & $.08^{* * * *}$ & & & & & & & & & \\
\hline 9 & .17 & .27 & $-.09 * * *$ & .00 & .02 & $-.17^{* * *}$ & $-.11^{* * *}$ & $-.09 * * *$ & $-.11^{* * *}$ & -.03 & & & & & & & & \\
\hline 10 & .28 & .52 & -.01 & $-.05^{* *}$ & -.03 & $-.07^{* *}$ & $-.12^{* * *}$ & $-.10^{* * *}$ & $-.06^{* *}$ & -.01 & $.51^{* * *}$ & & & & & & & \\
\hline 11 & .15 & .41 & $-.13^{* * *}$ & $.04^{\dagger}$ & .01 & $-.13^{* * *}$ & $-.07 * * *$ & $-.08 * * *$ & $-.06^{* *}$ & $-.06^{* *}$ & $.62^{* * * *}$ & $-.13^{* * *}$ & & & & & & \\
\hline 12 & .53 & .58 & $.08^{* * *}$ & $-.07 * * *$ & $.09 * * *$ & $.05 *$ & $.10^{* * *}$ & $.10^{* * *}$ & .03 & $.05 *$ & $-.32^{* * *}$ & $-.09 * * *$ & $-.20^{* * *}$ & & & & & \\
\hline 13 & .43 & .58 & .00 & $-.09 * * *$ & -.01 & $.09^{* * *}$ & .00 & .01 & .02 & $.08^{* * *}$ & $-.18^{* * *}$ & .03 & $-.14^{* * *}$ & $-.14^{* * *}$ & & & & \\
\hline 14 & .31 & .50 & $-.08^{* * *}$ & $-07^{* * * *}$ & $-.06 * *$ & $.06^{* *}$ & $-.10^{* * *}$ & $-.11^{* * *}$ & .03 & $-.10^{* * *}$ & $-.22^{* * *}$ & $-.06^{* *}$ & $-.12^{* * *}$ & $.07 * *$ & $-.14^{* * *}$ & & & \\
\hline 15 & .55 & .56 & $.04^{+}$ & .01 & -.02 & .00 & $-.05 *$ & $-.05^{* *}$ & $.05 *$ & -.02 & $-.25^{* * *}$ & $.07 * * *$ & $-.19 * * *$ & .03 & .01 & $.06 * *$ & & \\
\hline 16 & .38 & .52 & $.05^{*}$ & $.06^{* *}$ & $-.19 * * *$ & .03 & $-.15^{* * *}$ & $-.16^{* * *}$ & $.06^{* *}$ & $-.17^{* * *}$ & $-.17^{* * *}$ & $.14^{* * *}$ & $-.15^{* * *}$ & $.05 *$ & $.09 * * *$ & .03 & $.24^{* * * *}$ & \\
\hline 17 & .06 & .24 & .01 & $.19^{* * *}$ & $-.08 * * *$ & .03 & $-.04 *$ & $-.05^{*}$ & .03 & $-.07 * *$ & $-.11^{* * *}$ & $-.05 * *$ & $-.08 * * *$ & -.03 & $-.11^{* * *}$ & $-.08^{* * * *}$ & .00 & -.03 \\
\hline
\end{tabular}

Note. 1 = Satisfaction with Life; $2=$ Net Worth; $3=$ Income; $4=$ Gender $\left(1=\right.$ male); $5=$ Age; $6=$ Age $^{2} ; 7=$ Married $(1=$ yes $) ; 8=$ Retired $(1=$ yes); $9=\%$ of Unearned Wealth Sources; 10 = Wealth Source: Inheritance ( 1 = yes); 11 = Wealth Source: Spouse/Partner $(1=$ yes); 12 = Wealth Source: Saved Wages $(1=$ yes); $13=$ Wealth Source: Business Profits/Assets ( 1 = yes); 14 = Wealth Source: Large Bonus ( 1 = yes); 15 = Wealth Source: Personal Investments ( 1 = yes); 16 = Wealth Source: Profit from Property $(1=$ yes); 17 = Wealth Source: Other $(1=$ yes $)$ 
Table 2. Step-wise regression predicting life satisfaction from net worth groups (Study 1).

\begin{tabular}{|c|c|c|c|c|}
\hline Predictor Variable & Step 1 & Step 2 & Step 3 & Step 4 \\
\hline$\$ 3-7.9 \mathrm{M}$ & .01 & .01 & $\begin{array}{l}-.01 \\
\end{array}$ & $\begin{array}{l}-.01 \\
\end{array}$ \\
\hline$\$ 8-14.9 \mathrm{M}$ & $.05 *$ & $.04^{\dagger}$ & $.06 * *$ & $.06 * *$ \\
\hline$\$ 15 \mathrm{M}+$ & .02 & .03 & .03 & $.04^{\dagger}$ \\
\hline Gender (1 = male) & & $-.05 *$ & $-.05 *$ & $-.06 * *$ \\
\hline Age & & .08 & .06 & .06 \\
\hline $\mathrm{Age}^{2}$ & & .06 & .04 & .05 \\
\hline Married (1 = yes) & & $.11^{* * *}$ & $.10 * * *$ & $.10 * * *$ \\
\hline Retired ( 1 = yes) & & $.07 * *$ & $.05^{\dagger}$ & $.04^{\dagger}$ \\
\hline Brazil (1 = yes) & & & $.06^{* *}$ & $.06^{* *}$ \\
\hline China $(1=$ yes $)$ & & & $-.21^{* * *}$ & $-.20 * * *$ \\
\hline Hong Kong $(1=$ yes $)$ & & & $-.05 *$ & $-.05 *$ \\
\hline India (1 = yes) & & & .02 & .02 \\
\hline Ireland (1 = yes) & & & $-.06 * *$ & $-.06 * *$ \\
\hline Japan (1 = yes) & & & $-.21^{* * *}$ & $-.21 * * *$ \\
\hline Mexico $(1=$ yes $)$ & & & $.06^{* *}$ & $.06^{* *}$ \\
\hline Monaco (1 = yes) & & & $.05^{*}$ & $.05^{*}$ \\
\hline Qatar (1 = yes) & & & .02 & .02 \\
\hline Saudi Arabia (1 = yes) & & & $.10 * * *$ & $.10^{* * *}$ \\
\hline Singapore (1 = yes) & & & $-.06 * *$ & $-.06^{* *}$ \\
\hline South Africa $(1=$ yes $)$ & & & .01 & .01 \\
\hline Spain $(1=$ yes $)$ & & & $.05^{*}$ & $.05 *$ \\
\hline Switzerland (1 = yes) & & & .03 & $.04^{+}$ \\
\hline United Arab Emirates (1 = yes) & & & .01 & .01 \\
\hline United Kingdom $(1=$ yes $)$ & & & .00 & .00 \\
\hline \% of Unearned Wealth Sources & & & & $-.05 *$ \\
\hline$\Delta R^{2}$ & .00 & .05 & .12 & .00 \\
\hline$\Delta \mathrm{F}$ & 1.98 & 23.38 & 18.12 & 5.48 \\
\hline Total $\mathrm{R}^{2}$ & .00 & .06 & .17 & .17 \\
\hline $\mathrm{F}$ & 1.98 & $15.39 * * *$ & $17.88^{* * *}$ & $17.43^{* * *}$ \\
\hline d.f. & 3, 2084 & 8, 2079 & 24, 2063 & 25,2062 \\
\hline
\end{tabular}

$\dagger \mathrm{p}<.10,{ }^{*} \mathrm{p}<.05,{ }^{* *} \mathrm{p}<.01,{ }^{* * *} \mathrm{p}<.001$

Note: Respondents with a net worth of \$1.5 -2.9M, and from the United States, serve as the reference group for wealth comparisons and country comparisons, respectively. 
The Happiness of Millionaires 34

Table 3. Satisfaction with life scores (1-7 scale) by wealth level (Study 1)

\begin{tabular}{ccc}
\hline$N$ & Wealth Level & Satisfaction with Life \\
\hline 1035 & $\$ 1.5-2.9 \mathrm{M}$ & $5.79(1.12)$ \\
601 & $\$ 3-7.9 \mathrm{M}$ & $5.81(1.21)$ \\
247 & $\$ 8-14.9 \mathrm{M}$ & $5.97(1.04)$ \\
246 & $\$ 15 \mathrm{M}+$ & $5.84(1.20)$ \\
\hline
\end{tabular}

Note. Standard deviations are listed in parentheses. 
Table 4. Satisfaction with life scores (1-7 scale) by percent of unearned wealth sources (Study 1)

\begin{tabular}{ccc}
\hline$N$ & $\begin{array}{c}\text { Percent of Unearned } \\
\text { Wealth Sources }\end{array}$ & Happiness \\
\hline 1337 & $0 \%$ & $5.88(.03)$ \\
10 & $14 \%$ & $5.56(.35)$ \\
26 & $17 \%$ & $5.22(.21)$ \\
85 & $20 \%$ & $5.86(.12)$ \\
98 & $25 \%$ & $5.49(.11)$ \\
5 & $29 \%$ & $5.88(.47)$ \\
100 & $33 \%$ & $5.88(.11)$ \\
27 & $40 \%$ & $5.90(.22)$ \\
279 & $50 \%$ & $5.75(.07)$ \\
13 & $67 \%$ & $6.02(.29)$ \\
108 & $100 \%$ & $5.66(.10)$ \\
\hline
\end{tabular}

Note. Standard errors are listed in parentheses. This model includes covariates included in Table 2. 
Table 5. Step-wise regression predicting life satisfaction from net worth and income groups (Study 1).

\begin{tabular}{|c|c|c|c|c|}
\hline Predictor Variable & Step 1 & Step 2 & Step 3 & Step 4 \\
\hline \multicolumn{5}{|l|}{ Net worth } \\
\hline$\$ 3-7.9 \mathrm{M}$ & .00 & .01 & -.01 & -.01 \\
\hline$\$ 8-14.9 \mathrm{M}$ & $.05^{*}$ & $.04^{\dagger}$ & $.06^{* *}$ & $.06 * *$ \\
\hline$\$ 15 \mathrm{M}+$ & .01 & .03 & .03 & $.04^{\dagger}$ \\
\hline \multicolumn{5}{|l|}{ Income } \\
\hline$\$ 50-99 K$ & -.01 & -.01 & .01 & .01 \\
\hline$\$ 100-149 K$ & -.02 & -.02 & .01 & .01 \\
\hline$\$ 150-199 K$ & $-.05 *$ & $-.04^{\dagger}$ & -.01 & -.01 \\
\hline$\$ 200-249 K$ & $-.04^{\dagger}$ & -.03 & -.02 & -.02 \\
\hline$\$ 250-499 K$ & .01 & -.01 & -.02 & -.02 \\
\hline$\$ 500-999 K$ & $.12 * * *$ & -.03 & -.04 & -.04 \\
\hline$\$ 1+\mathrm{M}$ & -.02 & -.03 & $-.05 *$ & $-.05 *$ \\
\hline Gender ( 1 = male $)$ & & $-.06 *$ & $-.06 * *$ & $-.07 * *$ \\
\hline Age & & .09 & .07 & .06 \\
\hline $\mathrm{Age}^{2}$ & & .06 & .04 & .05 \\
\hline Married (1 = yes) & & $.11^{* * *}$ & $.11^{* * *}$ & $.10^{* * *}$ \\
\hline Retired (1 = yes) & & .08 & .07 & .07 \\
\hline Brazil (1 = yes) & & & $.06 * *$ & $.06 * *$ \\
\hline China (1 = yes) & & & $-.21 * * *$ & $-.20 * * *$ \\
\hline Hong Kong ( 1 = yes) & & & $-.05 *$ & $-.05^{*}$ \\
\hline India (1 = yes) & & & .01 & .02 \\
\hline Ireland ( 1 = yes) & & & $-.06 * *$ & $-.06^{* *}$ \\
\hline Japan $(1=$ yes $)$ & & & $-.21^{* * *}$ & $-.21 * * *$ \\
\hline Mexico $(1=$ yes $)$ & & & $.06 * *$ & $.06^{* *}$ \\
\hline Monaco $(1=$ yes $)$ & & & $.05^{*}$ & $.05^{*}$ \\
\hline Qatar (1 = yes) & & & .02 & .02 \\
\hline Saudi Arabia $(1=$ yes $)$ & & & $.10^{* * *}$ & $.10^{* * *}$ \\
\hline Singapore $(1=$ yes $)$ & & & $-.07 * *$ & $-.07 * *$ \\
\hline South Africa ( 1 = yes $)$ & & & .01 & .01 \\
\hline Spain (1 = yes) & & & $.05^{*}$ & $.05^{*}$ \\
\hline Switzerland $(1=$ yes $)$ & & & $.04^{+}$ & $.04^{\dagger}$ \\
\hline United Arab Emirates ( 1 = yes) & & & .01 & .01 \\
\hline United Kingdom (1 = yes) & & & .00 & .00 \\
\hline$\%$ of Unearned Wealth Sources & & & & $-.05 *$ \\
\hline$\Delta R^{2}$ & .03 & .03 & .12 & .00 \\
\hline$\Delta \mathrm{F}$ & 5.42 & 14.73 & 18.18 & 5.10 \\
\hline Total $\mathrm{R}^{2}$ & .03 & .06 & .18 & .18 \\
\hline $\mathrm{F}$ & $5.42 * * *$ & $8.64^{* * *}$ & $14.12^{* * *}$ & $13.87^{* * *}$ \\
\hline d.f. & 10, 2077 & 15, 2072 & 31, 2056 & 32,2055 \\
\hline
\end{tabular}

$\dagger \mathrm{p}<.10, * \mathrm{p}<.05, * * \mathrm{p}<.01, * * * \mathrm{p}<.001$

Note. Respondents with net worth of $\$ 1.5-2.9 \mathrm{M}$, income of $<\$ 50 \mathrm{~K}$, and from the United States, serve as the reference group for wealth comparisons, income comparisons and country comparisons, respectively. 
Table 6. Correlation Matrix (Study 2).

\begin{tabular}{|c|c|c|c|c|c|c|c|c|c|c|c|c|c|c|c|c|c|c|c|c|c|}
\hline & $M$ & $S D$ & 1 & 2 & 3 & 4 & 5 & 6 & 7 & 8 & 9 & 10 & 11 & 12 & 13 & 14 & 15 & 16 & 17 & 18 & 19 \\
\hline 1 & 7.84 & 1.54 & & & & & & & & & & & & & & & & & & & \\
\hline 2 & 1.79 & .96 & .03 & & & & & & & & & & & & & & & & & & \\
\hline 3 & 4.00 & 1.96 & $-.04^{\dagger}$ & $.50^{* * *}$ & & & & & & & & & & & & & & & & & \\
\hline 4 & .73 & .44 & .03 & $.08^{* * *}$ & -.01 & & & & & & & & & & & & & & & & \\
\hline 5 & 54.48 & 12.76 & $.22^{* * *}$ & -.03 & $-.30^{* * *}$ & $.16^{* * *}$ & & & & & & & & & & & & & & & \\
\hline 6 & & & $.21^{* * *}$ & -.02 & $-.29 * * *$ & $.16^{* * *}$ & $.99 * * *$ & & & & & & & & & & & & & & \\
\hline 7 & .82 & .38 & $.16^{* * *}$ & $-.06 *$ & $-.06 *$ & $.05 *$ & $.23^{* * *}$ & $.21^{* * *}$ & & & & & & & & & & & & & \\
\hline 8 & 1.71 & 1.23 & $.18^{* * *}$ & $.04^{\dagger}$ & .03 & $.15^{* * *}$ & $.29 * * *$ & $.28^{* * *}$ & $.38 * * *$ & & & & & & & & & & & & \\
\hline 9 & .30 & .46 & $.18^{* * *}$ & $-.09 * * *$ & $-.37 * * *$ & $.05 *$ & $.58^{* * *}$ & $.59 * * *$ & $.13^{* * *}$ & $.09 * * *$ & & & & & & & & & & & \\
\hline 10 & .19 & .29 & -.01 & -.01 & .01 & $-.23 * * *$ & $-.13^{* * *}$ & $-.11^{* * *}$ & $-.04^{\dagger}$ & .01 & $-.08^{* * *}$ & & & & & & & & & & \\
\hline 11 & .25 & .43 & $-.05^{*}$ & -.01 & -.03 & $-.11 * * *$ & $-.13^{* * *}$ & $-.11^{* * *}$ & $-.08^{* * *}$ & .02 & $-.06^{* *}$ & $.70^{* * *}$ & & & & & & & & & \\
\hline 12 & .18 & .39 & .00 & -.01 & -.02 & $-.26 * * *$ & $-.06 * * *$ & $-.05 *$ & $.07 * *$ & -.03 & .01 & $.54 * * *$ & $.20^{* * *}$ & & & & & & & & \\
\hline 13 & .55 & .50 & $-.04^{\dagger}$ & $-.12 * * *$ & $-.17^{* * *}$ & .03 & $.09 * * *$ & $.09 * * *$ & $.04^{\dagger}$ & $-.06 * *$ & $.14 * * *$ & $-.24 * * *$ & -.02 & $.06^{* *}$ & & & & & & & \\
\hline 14 & .16 & .36 & .00 & $.15^{* * *}$ & $.04^{\dagger}$ & $.08^{* * *}$ & -.03 & -.03 & -.03 & .02 & $-.05 *$ & $-.15^{* * *}$ & -.03 & $-.07 * *$ & $-.15^{* * *}$ & & & & & & \\
\hline 15 & .13 & .33 & $-.09 * * *$ & $.07^{* * *}$ & $.14^{* * *}$ & $.05 *$ & $-.13^{* * *}$ & $-.12 * * *$ & .01 & -.02 & $-.09 * * *$ & $-.14 * * *$ & $-.08^{* * *}$ & $.05 *$ & $.16^{* * *}$ & $.08^{* * *}$ & & & & & \\
\hline 16 & .55 & .50 & .00 & $-.04^{\dagger}$ & -.02 & -.02 & .01 & .01 & .04 & $-.04^{\dagger}$ & .02 & $-.26 * * *$ & -.01 & $.04 *$ & $.17^{* * *}$ & -.02 & $.15^{* * *}$ & & & & \\
\hline 17 & .34 & .47 & $-.07 * *$ & .01 & $.10^{* * *}$ & $-.04^{\dagger}$ & $-.14^{* * *}$ & $-.14^{* * *}$ & .02 & -.01 & $-.14^{* * *}$ & $-.18^{* * *}$ & .01 & .03 & $.06^{* *}$ & $.07^{* * *}$ & $.19^{* * *}$ & $.28^{* * *}$ & & & \\
\hline 18 & .01 & .10 & .03 & .02 & .00 & .02 & $.04 *$ & $.05^{*}$ & -.03 & .03 & $.06 *$ & -.02 & .01 & .02 & -.01 & $-.05^{*}$ & -.03 & -.02 & -.01 & & \\
\hline 19 & 1.77 & 1.61 & $-.13 * * *$ & -.02 & $.08^{* *}$ & $.07 * * *$ & $-.28 * * *$ & $-.27 * * *$ & $-.10^{* * *}$ & $-.10^{* * *}$ & $-.20 * * *$ & -.02 & .03 & -.02 & -.01 & .04 & $.05^{*}$ & -.02 & $.04^{\dagger}$ & $-.05 *$ & \\
\hline 20 & 3.24 & 1.62 & $-.12 * * *$ & -.05 & $.10^{* *}$ & -.02 & $-.16 * * *$ & $-.16^{* * *}$ & -.01 & $-.11^{* * *}$ & $-.15^{* * *}$ & -.04 & -.02 & .03 & .05 & .01 & $.08^{*}$ & .04 & $.07^{*}$ & .02 & $\begin{array}{l}.33^{* *} \\
*\end{array}$ \\
\hline
\end{tabular}

${ }^{\dagger} p<.10, * p<.05, * * p<.01, * * * p<.001$

Note. 1 = Current Happiness; 2 = Net Worth; $3=$ Income; $4=$ Gender $(1=$ male $) ; 5=$ Age; $6=$ Age $; 7=$ Married $(1=$ yes $) ; 8=$ Children; $9=$ Retired $(1=$ yes $) ; 10=\%$ of

Unearned Wealth Sources; 11 = Wealth Source: Inheritance ( 1 = yes); $12=$ Wealth Source: Spouse/Partner $(1=$ yes $)$; $13=$ Wealth Source: Saved Wages $(1=$ yes $)$; $14=$ Wealth Source: Business Profits/Assets ( 1 = yes); 15 = Wealth Source: Large Bonus ( 1 = yes); 16 = Wealth Source: Personal Investments $(1=$ yes $) ; 17$ = Wealth Source: Profit from Property ( 1 = yes); 18 = Wealth Source: Other $(1$ = yes); 19 = Increase for “ 1 point”; 20 = Increase for "perfect 10” 
Table 7. Step-wise regression predicting happiness from net worth groups (Study 2).

\begin{tabular}{|c|c|c|c|c|}
\hline Predictor Variable & Step 1 & Step 2 & Step 3 & Step 4 \\
\hline$\$ 2-4.9 \mathrm{M}$ & .02 & .01 & .01 & .01 \\
\hline$\$ 5-9.9 \mathrm{M}$ & -.04 & -.03 & -.01 & -.02 \\
\hline$\$ 10 \mathrm{M}+$ & $.04^{\dagger}$ & $.05^{*}$ & $.05 *$ & $.06 *$ \\
\hline Gender (1 = male) & & -.02 & -.02 & -.03 \\
\hline Age & & .09 & .06 & .02 \\
\hline Age $^{2}$ & & .04 & .04 & .08 \\
\hline Married (1 = yes) & & $.08^{* *}$ & $.09 * * *$ & $.09 * * *$ \\
\hline Children (1 = yes) & & $.12^{* * *}$ & .03 & .04 \\
\hline Retired ( 1 = yes $)$ & & $.10^{* * *}$ & $.08 * *$ & $.08 * *$ \\
\hline Brazil (1 = yes) & & & $.06^{* *}$ & $.06^{* *}$ \\
\hline China (1 = yes) & & & $-.23 * * *$ & $-.24 * * *$ \\
\hline Hong Kong ( 1 = yes) & & & $-.07 * *$ & $-.07 * *$ \\
\hline India (1 = yes) & & & .00 & .01 \\
\hline Ireland (1 = yes) & & & -.04 & -.03 \\
\hline Japan (1 = yes) & & & $-.13^{* * *}$ & $-.13^{* * *}$ \\
\hline Mexico $(1$ = yes $)$ & & & .02 & .02 \\
\hline Monaco (1 = yes $)$ & & & $.11^{* * *}$ & $.11^{* * *}$ \\
\hline Qatar (1 = yes) & & & $.12^{* * *}$ & $.13^{* * *}$ \\
\hline Saudi Arabia $(1=$ yes $)$ & & & $.11^{* * *}$ & $.11^{* * *}$ \\
\hline Singapore $(1=$ yes $)$ & & & $-.06 *$ & $-.06 *$ \\
\hline South Africa $(1=$ yes $)$ & & & -.04 & -.04 \\
\hline Spain $(1=$ yes $)$ & & & $-.04^{\dagger}$ & -.04 \\
\hline Switzerland (1 = yes) & & & -.01 & .00 \\
\hline United Arab Emirates $(1=$ yes $)$ & & & .01 & .01 \\
\hline United Kingdom (1 = yes) & & & -.01 & -.01 \\
\hline$\%$ of Unearned Wealth Sources & & & & $-.05^{*}$ \\
\hline$\Delta R^{2}$ & .00 & .08 & .12 & .00 \\
\hline$\Delta \mathrm{F}$ & 2.16 & 25.99 & 15.73 & 4.10 \\
\hline Total $\mathrm{R}^{2}$ & .00 & .09 & .20 & .21 \\
\hline $\mathrm{F}$ & $2.16^{\dagger}$ & $18.10 * * *$ & $17.48^{* * *}$ & $16.99 * * *$ \\
\hline d.f. & 3,1730 & 9, 1724 & 25,1708 & 26,1707 \\
\hline
\end{tabular}

$\dagger \mathrm{p}<.10,{ }^{*} \mathrm{p}<.05,{ }^{* *} \mathrm{p}<.01,{ }^{* * *} \mathrm{p}<.001$

Note: Respondents with a net worth of \$1-1.9M, and from the United States, serve as the reference group for wealth comparisons and country comparisons, respectively. 
Table 8. Happiness with Life in General scores (1-10 scale) by Wealth Level (Study 2)

\begin{tabular}{ccc}
\hline$N$ & Wealth Level & Happiness \\
\hline 993 & $\$ 1-1.9 \mathrm{M}$ & $7.81(1.54)$ \\
654 & $\$ 2-4.9 \mathrm{M}$ & $7.87(1.53)$ \\
176 & $\$ 5-9.9 \mathrm{M}$ & $7.72(1.62)$ \\
194 & $\$ 10 \mathrm{M}+$ & $8.03(1.47)$ \\
\hline
\end{tabular}

Note. Standard deviations are listed in parentheses. 
Table 9. Happiness with Life in General scores (1-10 scale) by Percent of Unearned Wealth Sources (Study 2)

\begin{tabular}{ccc}
\hline$N$ & $\begin{array}{c}\text { Percent of Unearned } \\
\text { Wealth Sources }\end{array}$ & Happiness \\
\hline 1195 & $0 \%$ & $7.89(.04)$ \\
8 & $14 \%$ & $8.04(.52)$ \\
24 & $17 \%$ & $8.05(.30)$ \\
44 & $20 \%$ & $7.83(.21)$ \\
111 & $25 \%$ & $7.73(.14)$ \\
7 & $29 \%$ & $7.38(.54)$ \\
181 & $33 \%$ & $7.81(.11)$ \\
17 & $40 \%$ & $7.76(.34)$ \\
127 & $50 \%$ & $7.84(.13)$ \\
52 & $67 \%$ & $7.56(.22)$ \\
88 & $100 \%$ & $7.66(.16)$ \\
\hline
\end{tabular}

Note. Standard errors are listed in parentheses. This model includes covariates included in Table 6. 
Table 10. Predictions of wealth increase needed to gain 1 point in happiness on a 10-point scale (Study 2; $N=1760$ ).

\begin{tabular}{|c|c|c|c|c|c|c|c|}
\hline & No Increase & $10 \%$ Increase & $50 \%$ Increase & 100\% Increase & $500 \%$ Increase & $1000 \%$ Increase & Total \\
\hline$\$ 1-1.9 \mathrm{M}$ & $\begin{array}{c}316 \\
(35.8 \%)\end{array}$ & $\begin{array}{c}64 \\
(7.3 \%)\end{array}$ & $\begin{array}{c}170 \\
(19.3 \%)\end{array}$ & $\begin{array}{c}195 \\
(22.1 \%)\end{array}$ & $\begin{array}{c}94 \\
(10.7 \%)\end{array}$ & $\begin{array}{c}43 \\
(4.9 \%)\end{array}$ & $\begin{array}{c}882 \\
(100.0 \%)\end{array}$ \\
\hline$\$ 2-4.9 \mathrm{M}$ & $\begin{array}{c}207 \\
(36.9 \%)\end{array}$ & $\begin{array}{c}46 \\
(8.2 \%)\end{array}$ & $\begin{array}{c}102 \\
(18.2 \%)\end{array}$ & $\begin{array}{c}126 \\
(22.5 \%)\end{array}$ & $\begin{array}{c}52 \\
(9.3 \%)\end{array}$ & $\begin{array}{c}28 \\
(5.0 \%)\end{array}$ & $\begin{array}{c}561 \\
(100.0 \%)\end{array}$ \\
\hline$\$ 5-9.9 M$ & $\begin{array}{c}57 \\
(37.7 \%)\end{array}$ & $\begin{array}{c}9 \\
(6.0 \%)\end{array}$ & $\begin{array}{c}24 \\
(15.9 \%)\end{array}$ & $\begin{array}{c}33 \\
(21.9 \%)\end{array}$ & $\begin{array}{c}16 \\
(10.6 \%)\end{array}$ & $\begin{array}{c}12 \\
(7.9 \%)\end{array}$ & $\begin{array}{c}151 \\
(100.0 \%)\end{array}$ \\
\hline$\$ 10 \mathrm{M}+$ & $\begin{array}{c}67 \\
(40.4 \%)\end{array}$ & $\begin{array}{c}13 \\
(7.8 \%)\end{array}$ & $\begin{array}{c}28 \\
(16.9 \%)\end{array}$ & $\begin{array}{c}38 \\
(22.9 \%)\end{array}$ & $\begin{array}{c}12 \\
(7.2 \%)\end{array}$ & $\begin{array}{c}8 \\
(4.8 \%)\end{array}$ & $\begin{array}{c}166 \\
(100.0 \%)\end{array}$ \\
\hline Total & $\begin{array}{c}647 \\
(36.8 \%)\end{array}$ & $\begin{array}{c}132 \\
(7.5 \%)\end{array}$ & $\begin{array}{c}324 \\
(18.4 \%)\end{array}$ & $\begin{array}{c}392 \\
(22.3 \%)\end{array}$ & $\begin{array}{c}174 \\
(9.9 \%)\end{array}$ & $\begin{array}{c}91 \\
(5.2 \%)\end{array}$ & $\begin{array}{c}1760 \\
(100.0 \%)\end{array}$ \\
\hline
\end{tabular}


The Happiness of Millionaires 42

Table 11. Predictions of wealth increase needed for a perfect “10” in happiness on a 10-point scale (Study 2; $N=887$ ).

\begin{tabular}{|c|c|c|c|c|c|c|c|}
\hline & No Increase & $10 \%$ Increase & $50 \%$ Increase & 100\% Increase & 500\% Increase & $1000 \%$ Increase & Total \\
\hline$\$ 1-1.9 \mathrm{M}$ & $\begin{array}{c}57 \\
(12.6 \%)\end{array}$ & $\begin{array}{c}8 \\
(1.8 \%)\end{array}$ & $\begin{array}{c}37 \\
(8.2 \%)\end{array}$ & $\begin{array}{c}110 \\
(24.4 \%)\end{array}$ & $\begin{array}{c}116 \\
(25.7 \%)\end{array}$ & $\begin{array}{c}123 \\
(27.3 \%)\end{array}$ & $\begin{array}{c}451 \\
(100.0 \%)\end{array}$ \\
\hline$\$ 2-4.9 \mathrm{M}$ & $\begin{array}{c}37 \\
(13.3 \%)\end{array}$ & $\begin{array}{c}12 \\
(4.3 \%)\end{array}$ & $\begin{array}{c}29 \\
(10.4 \%)\end{array}$ & $\begin{array}{c}58 \\
(20.9 \%)\end{array}$ & $\begin{array}{c}66 \\
(23.7 \%)\end{array}$ & $\begin{array}{c}76 \\
(27.3 \%)\end{array}$ & $\begin{array}{c}278 \\
(100.0 \%)\end{array}$ \\
\hline$\$ 5-9.9 \mathrm{M}$ & $\begin{array}{c}11 \\
(13.4 \%)\end{array}$ & $\begin{array}{c}4 \\
(4.9 \%)\end{array}$ & $\begin{array}{c}10 \\
(12.2 \%)\end{array}$ & $\begin{array}{c}14 \\
(17.1 \%)\end{array}$ & $\begin{array}{c}17 \\
(20.7 \%)\end{array}$ & $\begin{array}{c}26 \\
(31.7 \%)\end{array}$ & $\begin{array}{c}82 \\
(100.0 \%)\end{array}$ \\
\hline$\$ 10 \mathrm{M}+$ & $\begin{array}{c}9 \\
(11.8 \%)\end{array}$ & $\begin{array}{c}2 \\
(2.6 \%)\end{array}$ & $\begin{array}{c}10 \\
(13.2 \%)\end{array}$ & $\begin{array}{c}24 \\
(31.6 \%)\end{array}$ & $\begin{array}{c}18 \\
(23.7 \%)\end{array}$ & $\begin{array}{c}13 \\
(17.1 \%)\end{array}$ & $\begin{array}{c}76 \\
\text { (100.0\%) }\end{array}$ \\
\hline Total & $\begin{array}{c}114 \\
(12.9 \%)\end{array}$ & $\begin{array}{c}26 \\
(2.9 \%)\end{array}$ & $\begin{array}{c}86 \\
(9.7 \%)\end{array}$ & $\begin{array}{c}206 \\
(23.2 \%)\end{array}$ & $\begin{array}{c}217 \\
(24.5 \%)\end{array}$ & $\begin{array}{c}238 \\
(26.8 \%)\end{array}$ & $\begin{array}{c}887 \\
(100.0 \%)\end{array}$ \\
\hline
\end{tabular}


Table 12. Step-wise regression predicting current happiness from net worth and income groups (Study 2).

\begin{tabular}{|c|c|c|c|c|}
\hline Predictor Variable & Step 1 & Step 2 & Step 3 & Step 4 \\
\hline \multicolumn{5}{|l|}{ Net worth } \\
\hline$\$ 2-4.9 \mathrm{M}$ & .03 & .01 & .01 & .01 \\
\hline$\$ 5-9.9 \mathrm{M}$ & -.02 & -.03 & -.02 & -.02 \\
\hline$\$ 10 \mathrm{M}+$ & $.07 *$ & $.05^{*}$ & $.05^{*}$ & $.05^{*}$ \\
\hline \multicolumn{5}{|l|}{ Income } \\
\hline$\$ 50-99 K$ & $.14 * * *$ & $.07 *$ & .02 & .02 \\
\hline$\$ 100-149 \mathrm{~K}$ & $.13^{* * *}$ & $.09 * *$ & .05 & .05 \\
\hline$\$ 150-199 K$ & .05 & .05 & .01 & .01 \\
\hline$\$ 200-249 K$ & .03 & .03 & .00 & .00 \\
\hline$\$ 250-499 K$ & $.08 *$ & $.08 *$ & .05 & .05 \\
\hline$\$ 500-999 K$ & .03 & .03 & .00 & .00 \\
\hline$\$ 1+\mathrm{M}$ & .01 & .04 & .02 & .02 \\
\hline Gender (1 = male) & & -.02 & -.02 & -.04 \\
\hline Age & & .08 & .06 & .01 \\
\hline $\mathrm{Age}^{2}$ & & .04 & .04 & .08 \\
\hline Married (1 = yes) & & $.08 * *$ & $.09 * * *$ & $.09 * * *$ \\
\hline Children (1 = yes) & & $.11^{* * *}$ & .03 & .03 \\
\hline Retired (1 = yes) & & $.10^{* * *}$ & $.08 * *$ & $.08^{* *}$ \\
\hline Brazil (1 = yes) & & & $.06^{* *}$ & $.06^{* *}$ \\
\hline China (1 = yes) & & & $-.23 * * *$ & $-.23 * * *$ \\
\hline Hong Kong ( 1 = yes) & & & $-.07 * *$ & $-.07 * *$ \\
\hline India (1 = yes) & & & .00 & .01 \\
\hline Ireland ( 1 = yes) & & & $-.04^{\dagger}$ & $-.04^{\dagger}$ \\
\hline Japan (1 = yes) & & & $-.13^{* * *}$ & $-.13^{* * *}$ \\
\hline Mexico (1 = yes) & & & .02 & .02 \\
\hline Monaco (1 = yes) & & & $.11^{* * *}$ & $.12^{* * *}$ \\
\hline Qatar (1 = yes) & & & $.12^{* * *}$ & $.13^{* * *}$ \\
\hline Saudi Arabia (1 = yes) & & & $.11^{* * *}$ & $.12^{* * *}$ \\
\hline Singapore (1 = yes) & & & $-.06 *$ & $-.06 *$ \\
\hline South Africa (1 = yes) & & & -.04 & -.04 \\
\hline Spain $(1=$ yes $)$ & & & $-.04^{\dagger}$ & -.04 \\
\hline Switzerland (1 = yes) & & & -.01 & .00 \\
\hline United Arab Emirates ( $1=$ yes $)$ & & & .01 & .01 \\
\hline United Kingdom (1 = yes) & & & -.01 & -.01 \\
\hline$\%$ of Unearned Wealth Sources & & & & $-.05^{*}$ \\
\hline$\Delta R^{2}$ & .02 & .07 & .12 & .00 \\
\hline$\Delta \mathrm{F}$ & 2.96 & 23.25 & 15.51 & 4.31 \\
\hline Total $\mathrm{R}^{2}$ & .02 & .09 & .21 & .21 \\
\hline $\mathrm{F}$ & $2.96 * * *$ & $10.72 * * *$ & $13.84^{* * *}$ & $13.58^{* * *}$ \\
\hline d.f. & 10,1723 & 16,1717 & 32,1701 & 33,1700 \\
\hline
\end{tabular}

$\dagger \mathrm{p}<.10,{ }^{*} \mathrm{p}<.05,{ }^{* *} \mathrm{p}<.01,{ }^{* * *} \mathrm{p}<.001$

Note. Respondents with net worth of $\$ 1-1.9 \mathrm{M}$, income of $<\$ 50 \mathrm{~K}$, and from the United States, serve as the reference group for wealth comparisons, income comparisons and country comparisons, respectively. 